\title{
Out of Mind, Out of Sight: A Critical Appraisal of Social Initiatives to Curb Migration in Uttarakhand
}

\author{
Amanjeet Singh Sethi \\ Assistant Professor, FCBM, Amrapali Group of Institutes, Haldwani, Uttarakhand, India \\ E-Mail: amanjeetsinghsethi@gmail.com
}

Area/Section: Social Science.

Type of the Paper: Research Paper.

Type of Review: Peer Reviewed.

Indexed in: OpenAIRE.

DOI: http://doi.org/10.5281/zenodo.3531489.

Google Scholar Citation: $\underline{\text { IJMTS }}$

\section{How to Cite this Paper:}

Sethi, Amanjeet Singh. (2019). Out of Mind, Out of Sight: A Critical Appraisal of Social Initiatives to Curb Migration in Uttarakhand. International Journal of Management, Technology, and Social Sciences (IJMTS), 4(2), 59-68.

DOI: http://doi.org/10.5281/zenodo.3531489.

International Journal of Management, Technology, and Social Sciences (IJMTS)

A Refereed International Journal of Srinivas University, India.

IFSIJ Journal Impact Factor for $2018=4.764$

(C) With Author.

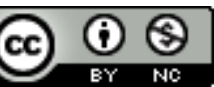

This work is licensed under a Creative Commons Attribution-Non Commercial 4.0 International License subject to proper citation to the publication source of the work.

Disclaimer: The scholarly papers as reviewed and published by the Srinivas Publications (S.P.), India are the views and opinions of their respective authors and are not the views or opinions of the SP. The SP disclaims of any harm or loss caused due to the published content to any party. 


\title{
Out of Mind, Out of Sight: A Critical Appraisal of Social Initiatives to Curb Migration in Uttarakhand
}

\author{
Amanjeet Singh Sethi \\ Assistant Professor, FCBM, Amrapali Group of Institutes, Haldwani, Uttarakhand, India \\ E-Mail: amanjeetsinghsethi@gmail.com
}

\begin{abstract}
The existing state of affairs in the hill and rural areas of Uttarakhand is very dangerous as the state has more than fifteen hundred ghost villages and this number is growing day in day out. The villagers from these places are moving out to plain areas within and outside the state mainly for employment opportunities and a variety of other reasons also contributes to this unfortunate process. Comprehending the urgency of the situation several individuals, non-government organizations, self help groups and the different agencies of the government have started a number of initiatives to curb this serious issue of migration. This research article makes an effort to study the circumstances, current scenario and predominant causes in relation to migration for the state of Uttarakhand. The research article mainly focusses on some of the successful cases of social initiatives attempted for helping to create a viable environment so that people do not have to migrate out of their home in search for facilities. The article concludes that such kind of social initiatives have the potential to stop the process of migration and to initiate reverse migration in the state but still a fair distance has to be covered to make this vision palpable.
\end{abstract}

Keywords: Migration, Employment, Social, Hills, Rural, Entrepreneurs, Infrastructure, Uttarakhand, Philanthropists.

\section{INTRODUCTION :}

Migration is a barometer to decipher the magnitude of transformation in the political, economic, social and cultural realm at the state as well as at the national stage. Exodus of human population also denotes a syndrome of imbalance in the fiscal and communal facet between the residence of emigrant and terminal of emigrant. One of the main reasons for migration in our country is the difference in growth and development in various parts of the country. According to the census report for the year 1951 the proportion of people living in the rural areas was about $83 \%$ of the country's total population. As per the documents from the reports of 2011 census the total population of our country was 120 Crores and is growing at a rate of $1.8 \%$ per annum. In the reports of 2011 census the people living in the urban areas was 37.7 Crores which is about $32 \%$ of the total population of our country. Accelerated industrialization and cluster of business-related activities in the urban areas are drawing emigrants from the villages across the country. India's urban areas population is generally clustered in some large towns and cities of the nation. The process of urbanization in our country has mainly taken place because of exodus of people from rural to urban areas. In the last five decades the proportion of people living in rural areas has dwindled from $80 \%$ to $69 \%$ [3].

As per the National Sample Survey 64th round July 2007 - June 2008 roughly one out of three persons in our country is an immigrant. Employment appears to be the main reason for immigration for the people living in villages and it can be gauged from the fact that more than 50\% of them have moved to urban areas due to livelihood reasons. Scrutiny of the statistics have revealed that majority of the people who have migrated were found to be working in some kind of commercial endeavours: for male the proportion of labourers has expanded from 50\% before migration to about $60 \%$ after migration in 
the villages and in the case of female it has expanded from $20 \%$ to $35 \%$ in the village areas. Finding job always seems to be a main concern for the people involved in the process of migration. One of the most interesting traits of migration is that the process of under-employment always takes place in this rural-urban journey.

The fundamental purpose behind migration can be generally elucidated with the help of two main categories, specifically, pull and push components. In Indian villages the main push component responsible for underdevelopment of the village economy is poverty because of this rural folk tends to move out of their homes. Mainly the deficiency of livelihood chances in the villages and superior livelihood circumstances in the cities captivate rural folk to move out of their homes. In the countryside stagnant agricultural progress and absence of growth in the other nonagricultural sectors has increased the occurrence of poverty, unemployment and underemployment in the countryside. Village folk since the beginning of civilization have migrated to the urban places with the anticipation of superior employment possibilities. The tale of emigration always has had its own share of agony and anguish as many juvenile changes into rag-pickers and households have to inhabit in inhumane environment in the towns and cities. A majority of people do not get job during the whole of the year and they shift between their village and city. Nevertheless, for the people with small land holdings who are always in perpetual liabilities shifting to urban cities for employment is the only chance left with them for survival [1].

\section{REVIEW OF LITERATURE :}

Arup Mitra in the research paper titled "Migration, Livelihood and Well-being: Evidence from Indian City Slums" makes an effort to find out the factors which are responsible for rural folk to get details about jobs in cities and if emigrants are capable to achieve higher manoeuvrability at their workplace are the two main parameters which are the focal point of this research paper. Conclusion is based on the ghetto survey which took place in four cities of India and this states the significance level of different unofficial routes through which employment is obtained in cities.
Nevertheless, these channels scale down the possibility of higher manoeuvrability as these channels expansion results of more supply of persons in relation to demand. The subject matter of higher manoeuvrability has also been studied by building a well-being index based on large number of social, economic, demographic, education and health-specific parameters. Even though results have shown betterment in the wellbeing of migrant's persons over a period of time, most of the migrant persons who have being living in urban areas for a longer period of time still have a low-quality life. Accordingly, this research paper gives support to better livelihood opportunities in the urban areas [14].

Thomas Solinski in his research work "NREGA and Labour Migration in India: Is Village Life what the 'Rural' Poor Want?" focus on Mahatma Gandhi National Rural Employment Guarantee Act popularly known as NREGRA which was a bellwether welfare scheme of the UPA launched in the year 2005. One of its predominant aims was to cut down rural - urban migration with the help of regionally accessible employment opportunities but in spite of some success the scheme was not able to achieve its main goals. According to government reports, non-governmental research and broadcasting agencies, the current research focus on the scheme's restricted influence, partially emanates from a delusion of labour migration i.e. poverty obstacle and slightly as a outcome of 'push-and-pull' economic variables. It maintains that this impression unjustifiably sees rural jobs and urban community as different stakeholders and believes that agriculture is what the poor wants, so installing poverty mainly as a village dilemma to be sorted out by rural development. Acknowledging reasons for NREGA's respective losses does not take into consideration the likelihood that migration for employment as just as an appealing activity. The belief of labour flexibility mainly as forced and compelled only by economic means dominates two components of reasons as why persons tends to move out of their homes: i.e. social variables and evolving perceptions of 'modernity'. The impoverished also have dreams which are not just limited to survival issues. NREGA has benefitted those persons who have no means for migration 
especially Scheduled Castes and Scheduled Tribes but are not probable to gain success in stopping labour movements in a meaningful manner. This research paper main progress goal is not to decrease migration but to enhance its environment both economical and social and to describe for the impoverished desires perspectives [18].

O. K. Belwal in his research "Hill Out-Migration from Uttarakhand: Access to Livelihood, Education and Other Determinants of Movement" state that Uttarakhand depicts a remorseful picture of outward migration at 29.7 per cent according to Census report of 1991 and bulk migrates to the cities for good livelihood chances. The argument for outward migration from hill districts to urban areas is related to a variety of parameters such as provincial underdevelopment, meagre landholding size, unemployment, under-employment and high natural growth of rural population. Previously the sequence of migration was from plain to hilly areas but these days the course of migration has reversed. These days migration is from hills to plain whence $40 \%$ of the total and $67 \%$ of the male population migrates to different parts of the nation. In the Garhwal division of the state there is no village or place where the phenomena of migration have not taken place. Particularly in outward migration the case has been that physically strong and capable move out of the state. While outward migration has its repercussion on different facets of villages in the state this paper endeavours to focus on this fundamental issue. This paper was pursued with the subsequent intentions: to examine various parameters of hill paces out-migration from village location of Uttarakhand; to study the logic of out-migration; to examine the repercussion of out-migration [2].

Prashant Kandari in his research work titled "Migration Pattern and the increasing Participation of Females in the Economy of Hill Rural Areas: A Study of Pauri district in Uttarakhand" state that the always expanding migration from the hills places has consistently been a problem for the economy of these places. The migration has invariably been so sizable that the economy of Uttarakhand has been described as "money order economy". To make this migration problem even more difficult are the various parameters such as absence of infrastructural facilities, lack of employment and livelihood chances. Inadequately developed prime sector has always continued to be a primary parameter but that too has singular created only an origin of livelihood for the people staying in these places. In the middle of these conditions the women of the hill districts of Uttarakhand have taken all the strain on themselves. This has been mirrored in the growing presence of women in the economy of the state of Uttarakhand. This research work mainly aims upon the comparative analysis of migration and presence of labour in these areas on the basis of gender within the various sectors. The research work mainly comes up with the parameters which regulate the progress of that areas should mainly have [11]. Sangita Kumari in her study "Rural-Urban Migration in India: Determinants and Factors" state the information from 64th round NSSO in the year 2007-08 and reports from census 2011 which demonstrates expeditious growth in internal migration in the country. The rate of migration in the towns and cities was 35\% which was significantly greater than the rate of migration in the village areas which was $26 \%$. Amidst the migrants in the village areas almost $90 \%$ have left their homes and about 10\% from the cities. Although amid the migrants in the cities, about $60 \%$ have gone from the villages and around $40 \%$ from the cities. Therefore ruralurban migration perform a very vital function in the relation to the process of migration. The predicted outcome of the regression model on premise of cross section examination of thirty states and UTs convey that in finding rural-urban migration the importance parameters such as percentage of village population and rural literacy rate are highly significant, although the parameters such as rural poverty ratio, MNREGA employment generation in man days and rural urban wage difference was insignificant in determining the difference in rural- urban migration from the tabulation of sample states which were studied. Indicating contrast some social parameters such as economic factors which also have a significant position in describing the character and flow of rural- urban migration such as identical language which function commonly 
both at origin and destination places, distance between the places, the mindset and aspirations of migrants and so on [12]. Abhishek Negi, Deepak Kaushal and Chirag Singhal in their paper "Migration A Social Problem: A Study of Factors Responsible for Migration from Hills of Uttarakhand" focus on the fact that migration has evolved into a worldwide paradox in the current times and it has been deliberated regularly as an originator or fallout of growth. This paper makes an effort to review the different parameters that are accountable for migration in Uttarakhand and the actions that are being employed to curb it. Uttarakhand as a recently established state is facing the complication of migration. On the account of basic amenities, natural disaster and unemployment, males and young persons from hills are shuffling not only to cities and plains of Uttarakhand but also to other places. The places with geographical closeness not invariably assurance a dazzling opportunity to progress but alike then persons are moving to these places and this is a severe anxiety for the economy of Uttarakhand. Even though many actions have been taken by Government under different blueprints since the establishment of the state but the benefit is at a lackadaisical tempo [15].

\section{OBJECTIVES OF THE STUDY :}

The main objectives of the study are as follows:

- To examine the circumstances driving the existing process of migration in the state of Uttarakhand.

- To study the migration pattern for the state of Uttarakhand.

- To document the social initiatives taken to curb migration in Uttarakhand.

\section{MIGRATION IN UTTARAKHAND :}

In Uttarakhand migration has been an ancient mechanism. The anthropology and ethnography of hill areas of the state has been affected by a massive in-migration from different regions of the country. The condition has altered extensively in recent times with a great percentage of persons migrating out of the state with their family members mainly for employment and a better future. This has become an extensive experience in hill areas culminating in sheer decline in places such as Almora and Pauri Garhwal districts and hardly any increase in other hill districts of the state during the last few years [8].

A number of research reports have been undertaken in the last few years to understand the dynamics of outward migration and its affect on the local economy. The recent data on migration in the last few years shows that about $90 \%$ of the households disclosed that at least one person of their family migrated for employment in the recent past. Aforementioned extensive consequences of migration have also been disclosed by pervious research reports which of course have been escalated in the previous decade.

A differentiating characteristic of outwards migration in the state is its being of a principally lengthy period and that they mainly move to major cities and towns within as well as outside of Uttarakhand. Generally, about $80 \%$ of the population migrate for a considerably longer period of time. Almost about $10 \%$ of the population move out for a brief duration of two to six months which is as per the reports obtained in NSSO surveys. This is opposite to the sequence observed in various studies in different regions of the country which present the prevalence of brief duration regarding migration among the villages household. This is chiefly because of the statistic that a staggering percent of the population migrating out of the state are doing salaried jobs which are mainly for the life time of the individual [13].

According to the data only $17 \%$ of the people migrating are hired in government sector and additionally about $13 \%$ are persons who have migrated because of studies. In addition to the above about $12 \%$ persons of migrates are employed in household endeavours this mainly involve women migrants. Contradictory to this migrates from villages of Bihar or eastern Uttar Pradesh does not move out of primary sector prosperous areas in their states for short duration employment. Their comparably superior educational qualifications have helped them to explore employment opportunities in salaried jobs however inevitably not earning respectable income for majority of them.

Migrants have relatively superior educational 
qualifications as related to their non-migrants counterparts. In relation to the above fact migration generally pertain to moving of the population from hill areas to cities within and outside of the state of Uttarakhand. As per the reports and data from various organizations the number of 'ghost villages' have enormously increased over the last few years. These figures make up for more than half of the number of present households in the villages of Uttarakhand. If one moves to these villages the sight will be of sealed and depilated houses and desolate chunks of former cultivated agricultural land in many places in hill areas of the state. The migration trends and figures of the state of Uttarakhand overall present a very sorry state of affairs as this has become a cascading effect [17].

\section{CAUSES OF MIGRATION IN} UTTARAKHAND :

There are abundant causes which lead to migration of people from one place to another. The determinants can be principally classified into three main groups i.e. economic, social and environmental. The components inside the economic group are: differences in regional growth, job chances, rise in per capita income, income escalation and unequal allocation of enhancement of economic prosperity. The components associated to social group are: law and order, social clashes and discomfort, cracks in acculturation/urbanity, disparities in the accessible social chances and other comforts of life between groups of persons and sectors, social flexibility, social status desires, friend and family importance, appetite for achieving lifestyle, residential achievement. The components related to environmental group affecting migration are: situation of flood, drought, sea level rise, earth quack and so on. The main factors for rural to urban migration are discussed beneath [4] :

Population Strain: Accompanying the expansion of population strain on natural resources, primary sector land is intensifying with the each passing day. To perform the requirement of housing, infrastructure and so on the natural resources are getting exhausted. Additional people mean more demand on already strained resources available with the village households. This leads to decline in per capita income, per capita availability of land, fragmentation of land, low productivity in the primary sector. As per previous reports and studies near about $80 \%$ of the present-day farmers are now been turned into small farmers.

- Job Circumstances: Because of the burden due to growth in population the demand for economic earnings from the primary sector has elevated but at the same time the output has not increased at the same level. Additionally, with the growth of population and disintegration of large cultivated land into tiny landholding, primary sector activities have slowly been transformed to subsistence farming. Nearly all of the villages' folk have moved out of their native places to big towns and cities for employment opportunities in various types of industries. In cities various types of industries have the scope to take in these people as workers in different roles.

- Dearth of Basic Facilities: Dearth of employment activities in villages regions together with insufficient and nominal elements of elementary necessities like satisfactory education, health care facilities, financial institutions, inapproachable and unsuitable markets have also forced the village folks to move to cities.

- Weather Obstinate: The occurrences of changes in weather conditions have influenced the village environment in a number of ways. This has led to floods, droughts, increase in sea level rise and so on. These circumstances have also forced the people to move to cities from their homes.

- Enhancement in Communication and Transportation: Enhancement in communication and transportation convenience have diminished the geographical boundaries and contributed for the people to come together. The locations with approachable roads, communication and logistics facilities have boosted migration to the cities from the villages. In the times of lean period in the primary sector the rural people tend to move to cities for livelihood opportunities and they come back with the beginning of sowing season. Such type of 
seasonal and circular migration has always been a part of the history of Uttarakhand since the last few decades.

\section{SOCIAL INITIATIVES IN UTTARAKHAND :}

According to a famous proverb "A coin always has two sides" is equally and truly applicable for the state of Uttarakhand. The state is famous for its natural beauty and landscape but these features have even become in some sense as bane for the economy of the state. Arduous and hazardous landscapes have even forced the people to migrate out of the hill areas to plain areas within and outside the state of Uttarakhand. Absence of basic facilities and mainly employment opportunities has forced the people to migrate. In this blurred situation some individuals and organizations have taken upon themselves to fight with this social or in the case of Uttarakhand a national security issue. In the below mentioned paragraphs we will discuss some of these initiatives to encounter migration [16].

\section{CULTIVATING MUSHROOMS :}

A young woman Divya Rawat is cultivating mushrooms to fight migration and thus by this contributing to employment of the rural masses of the state. This effort of hers is further supporting in repopulating many so called 'ghost villages' in Uttarakhand. She was moved by the fact that the condition of maximize number of people migrating was very pitiful as they were involved in lowly work and drenched for a very small amount. She wished to do some work to correct these circumstances and the colossal drive came in the form of flash folds of 2013. She instantly left her job and went back to her native place.

She analyzed, examined, consulted and explored a variety of options to see what will be the best for correcting this situation. Finally, she zeroed on mushrooms because by cultivating this farmer can earn more than ten times when compared to other things such as potatoes or tomatoes. She looked for finest varieties that can be cultivated in the tough climatic conditions of the state and with present of little or no infrastructure facilities. She even started an enterprise named 'Soumya Foods Private Limited' to help the farmers to sell their products at the best available price.
Divya's efforts have started to bear fruits as the output of mushrooms has increased to a great extent and this venture of her is providing livelihood opportunities to many in the state. She has even started training people across the state. She even has aided persons to become entrepreneurs with a very little amount of money. Her enterprise has now become a profit-making entity and the numbers of people cultivating mushrooms have increased many folds. She with the help of other people has begun pinpointing the 'ghost villages' and initiated mushroom cultivating in these villages. She certainly has started influencing development as a few migrants have come back to the villages. Inwards migration will certainly not occur very soon but Divya is confident that this initiative of her will bring revolution in the times to come [10].

\section{ORGANIC FARMING :}

Neeraj Pokhriyal along with other young professionals coming from Uttarakhand has started an enterprise named 'Subear'. Migration in Uttarakhand was mainly because of the reason that development was primarily concentrated in plain areas and hill locations lagged behind in this race. Most of the job opportunities and economics activities were centred in plain areas of Uttarakhand which has led to extremely large income differences in plain areas and hill locations of the state. This is high time that is one sided growth and development paradox is corrected for the true progress of the state.

This social initiative was given a green signal by Mr. Subodh Uniyal the agriculture minister of Uttarakhand who was impressed by this beginning and stated that the state needed more such young professionals to contribute their stamina and time to such efforts. Subear the social initiative wants to amass abandoned and unoccupied agricultural farmland from farmers in far flung areas of the state and then utilize this for organic farming and other primary sector ventures that will bolster employment activities. The main target areas for this social initiative are organic farming along with eco-tourism. The minister has assured that the government will assist and advocate all such actions proposed at curbing migration from the hill regions of the state. 
Neeraj Pokhriyal who was the inspiration and brainchild behind Subear wants to engage about 15000 families staying in far flung areas of the state with employment and economic opportunities related with organic farming so that people do not have to migrate from their homes. In Uttarakhand there are about 1100 so called 'ghost villages' which are entirely unoccupied as there is not a single occupant living in these villages and the team of Subear wants to take over such places and transform them into a living heaven with job and economic opportunities. Subear wants to launch a mobile application which will help to link with all the farmers engaged in organic farming so that changes can to recommend in making the state a better place to live in [6].

\section{SCENTED STICKS :}

Kundal Van Panchayat is a far-flung area in the district of Nainital, Uttarakhand and this comes under the Haldwani forest division. Nevertheless because of lack of elementary facilities like employment, education, healthcare and so on, villagers have moved out of the rural locations to the plain areas within and outside the state. In an endeavour to arrange employment for the villagers living near the Van Panchayat as a deterrent to curb migration the Haldwani forest division has engrossed people who stay near Kundal Van Panchayat in producing scented sticks (herbal dhoop) from the curative and pungent herbs which grow naturally in these forest areas.

In the state of Uttarakhand, Van Panchayat has a very critical function in the operation of the local economy. These Van Panchayats just do not add only to flora and fauna of the place but also give employment and economic opportunities to the villagers staying near the forest areas. This social initiative is being executed with the help of women self-help groups as this will give then better employment and economic opportunities and in the long term this will help to curtail migration. The professionals are giving advice to these self-help groups with all the necessary technical and scientific support.

Scented sticks (herbal dhoop) are that kind of products which are a commercial success in the national and international markets. In the state of Uttarakhand the ingredients for these products are found growing naturally in the forest areas. The forest division with the help of various other agencies are providing all the necessary support to the rural peoples so that they can make these sticks a commercially viable commodity [7].

\section{HOMESTAY :}

In Uttarakhand as per the reports of the Rural Development and Migration Commission has about 1768 'ghost villages' in various hill areas of the state. The rate of migration has gone up to a great extent in the last few years. Between the years 2011 to 2017, 734 villages were fully abandoned by their residents and in another 565 villages the population was decreased by more than half. These figures along with others are a source of great concern for the state as well as the central government. HomeStay as a social initiative along with various other initiatives are a part of a larger policy to repopulate these so called 'ghost villages' in the state. HomeStay as a concept and part of rural development was started by a number of agencies in the state. The Government of India had started a scheme in the year 2015 in association with Uttarakhand Tourism Development Board to provide employment opportunities to the rural people. As per this scheme the income can be generated by the villagers by furnishing food and accommodation to the people visiting and staying in their homes. To make this concept popular the government has stated that like hotels, the homes under HomeStay are not required to be registered under the Sarai Act, 1867. This means they also exempted from paying corporate tax and the tax rate for water and electricity for them will be not as per the commercial rates.

General Bipin Rawat, present Chief of Army Staff (COAS) has urged former army personals to activity get associated with HomeStay projects in and around their village areas. The Indian Army has even nominated a representative who is coordinating with the former army personals and the Uttarakhand government to make the scheme of HomeStay a success. The favourable outcome of this scheme will go a long way in solving the migration problem of Uttarakhand to a great 
extent for the state government. From the central government viewpoint increase in the number of 'ghost villages' will endanger the national security of the country [5].

\section{TEA TOURISM :}

To control unwilling migration from the hill areas of Uttarakhand the state government has designed a project to encourage tourism in tea sector in the hill districts by enlarging the area under tea gardens. Uttarakhand Tea Development Board the flagship agency for this scheme has made a comprehensive plan by encouraging private sector to take an active part with the help of big investments. The board plans to increase the output of tea which in turn will contribute as a stimulus to increase the producer's income and give more employment to the local people. The main objective behind is that the traditional variety of tea in the hill districts is a success in the international market because of its different flavour and scent which is excellent for a human being health due to its anti-oxidant features which disinfect the body of infection and virus.

The board's main motive behind this initiative is to increase the export of the tea which in turn will give good revenue in the form of foreign exchange to the tea farmers. Uttarakhand wants to replicate the Darjeeling model in which tea is cultivated on the rolling hills which increases the scenic beauty of the place. The agriculture climate in the state is very convenient to the traditional variety of tea. The state wavy geographical conditions do not allow it to store water underground which is a supportive situation for growing tea in the state. The board has created a legal structure so the proposals under public private partnership can be taken off at the earliest. Day in day out the board is bringing more land under tea cultivation to boost output and with these more economic benefits to the locals.

The initiatives of the tea board are bearing fruits as the production of tea has increased to 70000 kilograms per annum and till date more than 4000 locals are getting some employment in the gardens and offices of Uttarakhand Tea Development Board. The board has even got a fund close to ₹100 Crores from the funding agency of the World Bank and National Bank for
Agriculture and Rural Development (NABARD). With the efforts of the board more tea gardens are gradually being established in the areas exposed to landslides and this also helps in the expansion of green cover which results in environmental enrichment [9].

\section{CONCLUSION :}

The state of Uttarakhand is being confronted with the issue of migration from the hill regions to the plain regions within and outside the state. As per the research reports and statistics there has been an accelerated expansion in the process of migration. This can be attributed to a variety of reasons such as dearth of elementary infrastructure, inferior connectivity, not up to mark healthcare framework, no employment opportunities or not even up to date education facilities. A number of social initiatives by individuals, nongovernment organizations, self help group or the different agencies of the government have started their efforts in their own manner to curtail this enormous problem of migration. The outcome of these social initiatives has given a ground to start the process of reverse migration in the state but still a fair distance is left to be covered before this dream turns into a reality. These social initiatives will only bear fruit when the participation of the community will increase in these kinds of initiatives. Having said that unless and until government and its agencies along with big philanthropists do not chip in these efforts will not make any great difference in the ground level.

\section{REFERENCES:}

[1] Bandyopadhyay Piyali (2017). Smart Village as an Instrument to Curb the Rural to Urban Migration in India. Real Corp, 2(6), 497-505.

[2] Belwal O.K. (2007). Hill Out-Migration from Uttarakhand: Access to Livelihood, Education and Other Determinants of Movement. Demography India, 36(1), 135-143.

[3] http://censusindia.gov.in/DigitalLibrary/brow sey earwise.aspx. Retrieved on 10/07/2019.

[4] http://www.uttarakhandpalayanayog.com/ pdf/English\%20version.pdf. Retrieved on 10/07/2019. 
[5] https://defenceaviationpost.com/army-chiefbipin-rawat-help-stop-migration-will-encouragehome-stay-projects-uttarakhand/ Retrieved on $10 / 07 / 2019$.

[6]

https://timesofindia.indiatimes.com/city/dehradun /young-professionals-start-subaer-to-curbmigration/articleshow/63274821.cms. Retrieved on $10 / 07 / 2019$.

[7] https://www.dailypioneer.com/2015/stateeditions/efforts-on-to-stop-migration-of-ruralpeople.htmlRetrieved on 10/07/2019.

[8]

https://www.downtoearth.org.in/coverage/econom y/why-this-abandoned-village-is-a-threat-touttarakhand-52154. Retrieved on 10/07/2019.

[9]

https://www.hindustantimes.com/dehradun/uttara khand-plans-tea-tourism-boost-to-curbmigration/story-pa8n4eqvtPGry75OBPzXQI.html Retrieved on 12/07/2019.

[10]

https://www.thebetterindia.com/64150/livelihoods -mushroom-uttarakhand-divya-rawat-socialentrepreneur/Retrieved on 12/07/2019.

[11] Kandari Prashant (2013). Migration Pattern and the increasing Participation of Females in the Economy of Hill Rural Areas: A Study of Pauri District in Uttarakhand. IOSR Journal of Humanities and Social Science, 17(5), 27-33.

[12] Kumari Sangita (2014). Rural-Urban Migration in India: Determinants and Factors. International Journal of Humanities and Social, 3(2), 161-180.

[13] Mamgain Rajendra and Reddy D.N. (2015). Outmigration from Hill Region of Uttarakhand: Magnitude. Challenges and Policy Options, Working Report, National Institute of Rural Development and Panchayati Raj.

[14] Mitra Arup (2010). Migration, Livelihood and Well-being: Evidence from Indian City Slums. Urban Studies, 47(7), 1371-1390.

[15] Negi Abhishek, Kaushal Deepak and Singhal Chirag (2016). Migration A Social Problem: A Study of Factors Responsible for Migration from
Hills of Uttarakhand. Journal Global Values, 7(1), 142-154.

[16] SethiAmanjeet Singh and Singhal B.P. (2015). Entrepreneurship with a Difference - To Make a Difference: A Critique of Social Entrepreneurs in Uttarakhand. Vidya International Journal of Management Research, 3(1-20), 5-15.

[17] Singhal B.P. and SethiAmanjeet Singh (2017). Developmental Competence Mapping of Uttarakhand as a Tourist Destination in India: A Critique, ELK Asia Pacific Journal of Marketing and Retail Management, 8(4), 1-13.

[18] Solinski Thomas (2012). NREGA and Labour Migration in India: Is Village Life what the 'Rural' Poor Want?.Journal of South Asian Studies, 1(1), 17-30. 